\title{
MULTI KRITERIA TERHADAP PENILAIAN PENYEBAB KEJADIAN RISIKO KECELAKAAN KERJA UNTUK PROYEK KONTRUKSI DENGAN METODE ANALYTICAL NETWORK PROCESS
}

\author{
Dwi Iryaning Handayani*), Tri Prihatiningsih \\ Jurusan Teknik Industri, Fakultas Teknik, Universitas Panca Marga, Probolinggo \\ Jalan Yos Sudarso 107, Pabean Dringu, Probolinggo
}

(Received: October 26, 2017/ Accepted: February 28, 2018)

\begin{abstract}
Abstrak
Permasalahan K3 di Indonesia masih kurang diperhatikan, padahal sektor konstruksi merupakan sektor yang berisiko terhadap kecelakaan kerja disamping sektor lainnya. Banyak faktor yang dapat memicu penyebab terjadinya risiko kecelakaan kerja. Oleh karena itu penting untuk diketahui potensi penyebab terjadinya risiko kecelakaan kerja sehingga tujuan penelitian ini melakukan penilaian penyebab risiko kecelakaan kerja pada proyek kontruksi. Metode yang digunakan untuk melakukan penilaian tersebut dengan metode ANP menggunakan sofware Matlab. Penyebab terjadinya risiko K3 pada bidang kontruksi didominasi oleh kriteria struktur 44\% dibandingkan dengan kriteria persiapan $17 \%$, kriteria sub struktur $21 \%$ dan kriteria finishing $19 \%$. Penyebab risiko kecelakaan kerja yang paling besar disebabkan oleh faktor manusia 77\%, faktor ini disebabkan karena perilaku tidak aman meliputi kurang pengetahuan K3, pekerja kurang disiplin, pekerja tidak menggunakan APD, komitmen K3 kurang, tidak mengikuti pelatihan K3, kesalahan transformasi informasi, Metode kontruksi tidak benar, Pondasi scaffolding tidak padat pada tempat yang datar. Sedangkan penyebab kecelakaan kerja lainnya seperti scaffolding ambruk, kabel terkena air konsleting, kabel terkelupas, tersentuh aliran listrik, lokasi becek, lumpur, amblas. Upaya dalam pengendalian risiko kecelakaan kerja yaitu perbaikan manajemen $K 3$ dan pelatihan K3 dalam meningkatkan komitmen K3 dengan adanya pengendalian risiko diharapkan dapat meminimalkan risiko (zero accident) pada pekerjaan kontruksi.
\end{abstract}

Kata kunci: Penilaian; Penyebab Risiko; Kecelakaan Kerja

\begin{abstract}
[Multi Criteria On the Assessment of Accidents Causes in Occupational Risk in Construction Project By Analytical Network Process Method] Even though the construction sector is a sector with high risk of occupational accidents beside other sectors, the problem of occupational health and safety (OHS) in contruction sector is still gaining less attention in Indonesia. Many factors can trigger the cause of occupational accidents risk. Therefore, it is important to understand the potential causes of occupational accidents risk. This research is intended to assess the risk of occupational accidents on construction projects. We use analytical network process (ANP) method running on Matlab software to perform the assessment. It is found that the cause of risk in OHS for construction sector is dominated by structure criterion (44\%), followed by preparation criterion (17\%), sub-structure criterion (21\%) and finishing criterion (19\%). The biggest cause of occupational accidents is human factor by $77 \%$, this factor is caused by unsafety behavior which include lack of knowledge in OHS, indisciplined workers, ignoring the use of personal protective equipment (PPE), lack of commitment in practicing OHS, no OHS training, missinformation, incorrect construction method, and scaffolding foundation is not solid on a flat area. While the cause of other occupational accidents includes collapsing scaffolding, wires exposed to water, peeled cable, unintentional touch of electrical current, muddy site, mud, and avalanche. Some efforts in controlling the risk of occupational accidents includes improving OHS management and OHS training to improve OHS commitment. It is expected that by controlling the risk, accidents in contruction work can be minimized (zero accident).
\end{abstract}

\footnotetext{
${ }^{*}$ Penulis Korespondensi.

e-mail: dwiiryaninghandayani@yahoo.co.id
}

Keywords: Assessment; Risk Causes; Work Accidents, 


\section{Pendahuluan}

Tingkat kecelakaan kerja pada sektor proyek kontruksi di Indonesia masih tinggi. Dengan jumlah angka kecelakaan kerja secara nasional yaitu 103.000 per tahun, dari jumlah tersebut 2.400 kasus diantaranya menyebabkan pekerja meninggal dunia (Kompas. com, 2015). Fenomena ini menunjukkan bahwa permasalahan K3 di Indonesia masih kurang diperhatikan, padahal sektor konstruksi merupakan sektor yang berisiko terhadap kecelakaan kerja di samping sektor lainnya. Hal ini dibuktikan oleh Adiyanto (2013) menyatakan bahwa setiap 100 ribu tenaga kerja terdapat 20 orang fatal akibat kecelakaan kerja di bidang kontruksi.

Pada umumnya industri bidang jasa kontruksi memiliki risiko kecelakaan kerja yang cukup tinggi. Risiko kecelakaan kerja yang paling sering terjadi yaitu terpukul, jatuh dari ketinggian yang sama, terbentur dan tersengat aliran listrik. Menurut Jamsostek (2010) risiko kecelakaan kerja ini cenderung serius bahkan seringkali mengakibatkan cacat tetap dan kematian. Risiko kecelakaan kerja yang terjadi di lingkungan proyek kontruksi sebagian besar $88 \%$ disebabkan karena perilaku yang tidak aman (unsafe action), 10\% kondisi lingkungan kerja yang tidak aman (unsafe condition) dan $2 \%$ tidak diketahui penyebabnya (Handayani, 2014).

Namun, Patriadini (2013) berpandangan bahwa penyebab utama timbulnya risiko kecelakaan kerja yaitu sikap pekerja yang enggan menggunakan APD, kurangnya kesadaran pekerja terhadap keselamatan diri sendiri, serta kurangnya pengetahuan pekerja terhadap bahaya yang ada di lingkungan kerja yang sebenarnya telah diatur dalam pedoman K3 konstruksi. Selain itu penyebab timbulnya risiko menurut Wirahadi Kusuma (2014) yaitu manajemen keselamatan kerja yang sangat lemah.

Oleh karena itu, perlu dilakukan penilaian peyebab risiko kecelakaan kerja di bidang jasa kontruksi dengan mempertimbangkan hubungan pengaruh antar kejadian risiko (kriteria) dan penyebab risiko (subkriteria). Untuk itu dilakukan pendekatan dengan Multi Criteria decision making (MCDM). Salah satu metode yang tepat menurut Haastrup dalam Bottero dan Ferreti (2011) dalam menangani permasalahan keterkaitan antar kriteria yaitu metode ANP.

Keunggulan metode ANP dapat menentukan penilaian kriteria dan sub-kriteria dari hubungan yang ada, serta mencari hubungan pengaruh antar kiteria dan sub-kriteria. Kriteria merupakan variabel kejadian risiko sedangkan untuk sub-kriteria merupakan penyebab dari kejadian risiko. Tujuan penelitian ini melakukan penilaian terhadap penyebab risiko kecelakaan kerja, sehingga dapat diketahui pemicu terjadinya risiko $\mathrm{K} 3$ yang pada proyek kontruksi

\section{Bahan dan Metode}

Sebelum dilakukan penilaian penyebab kejadian risiko dengan metode ANP, maka terlebih dahulu mengetahui kejadian risiko pada proyek kontruksi.
Adapun tahapan yang dilakukan dalam penelitian ini meliputi :

\section{Identifikasi Risiko dan Penilaian Risiko}

Identifikasi risiko merupakan hasil penelitian Handayani (2017a) yang ditunjukkan pada Tabel 1. Setelah didapatkan kejadian risiko pada proyek kontruksi maka tahap berikutnya dilakukan penilaian risiko yang mana kejadian risiko $(\mathrm{R})$ berdasarkan nilai probabilitas yang paling tinggi, dengan cara mengalihkam frekuensi atau kekerapan terjadinya kecelakaan (F) dengan keparahan dari akibat terjadinya kecelakaan (S). Probabilitas kejadian risiko yang paling tinggi sebesar 6 .

Skala frekuensi (F):

Nilai 1 : hampir tidak pernah terjadi/ sangat kecil kemungkinan terjadi.

Nilai 2 : mungkin terjadi/ jarang terjadi.

Nilai 3 : hampir pasti terjadi/ sangat besar kemungkinan terjadi/ sering terjadi atau terus menerus terjadi.

Skala keparahan :

Nilai 1: luka ringan/ sakit yang dapat diobati dengan pertolongan pertama/ kerusakan properti, kerugian materiil atau lingkungan kurang dari 5 juta, tidak berpotensi melanggar peraturan/ mencemari lingkungan.

Nilai 2: hilang hari kerja/ sakit yang dapat diobati dengan pertolongan medis tetapi tidak mengakibatkan cacat permanen/ kerusakan properti, kerugian materiil atau lingkungan antara 5 juta sampai dengan 50 juta, berpotensi melanggar peraturan/ mencemari lingkungan.

Nilai 3: luka berat/ luka yang dapat mengakibatkan cacat permanen/ sakit yang tidak dapat diobati/ kematian/ pelanggaran peraturan/ mencemari lingkungan.

Setelah diketahui risiko kecelakaan kerja, selanjutnya dilakukan penilaian menggunakan ANP menggunakan sofware Matlab, terhadap masingmasing penyebab risiko kecelakaan kerja. Adapun tahapan yang dilakukan dalam penilaian peyebab risiko kecelakaan kerja dengan metode ANP yaitu:

\section{Penentuan Goal, Kriteria, dan Sub Kriteria}

Langkah awal dalam perhitungan penilaian menggunakan metode ANP yaitu menentukan goal, kriteria, dan sub-kriteria. Goal yang ingin dicapai dalam perhitungan ini yaitu memprioritaskan risiko kecelakaan kerja pada proyek kontruksi. Kriteria adalah kejadian risiko pada proyek kontruksi yang dikelompokkan berdasarkan tahapan dalam pemetaan aktivitas proyek kontruksi, sub-kriteria adalah penyebab risiko kecelakaan kerja. 


\section{Identifikasi dan Validasi Hubungan}

Identifikasi dan validasi hubungan keterkaitan dilakukan dengan cara brainstorming dengan expert perusahaan yang berkompeten pada bidang K3 Identifikasi dan validasi hubungan berkaitan dengan nilai yang diberikan untuk mengetahui nilai prioritas pada masing - masing kriteria dan sub-kriteria.

\section{Model Analytical Network Process (ANP)}

Penyusunan model ANP dilakukan dengan bantuan software Matlab, dimana prosesnya diawali dengan pembuatan model klaster yang menunjukkan hubungan hirarki antara goal, kriteria dan sub-kriteria. Melalui model ini akan terlihat hubungan antar kriteria dan antar sub-kriteria.

\section{Perhitungan Bobot Kriteria dan Sub Kriteria}

Perhitungan bobot kriteria dan sub-kriteria bertujuan untuk memperoleh nilai prioritas pada masing-masing kriteria dan sub-kriteria. Nilai kriteria dan sub-kriteria didapatkan dengan membandingkan masing - masing kriteria dengan kriteria lainnya, subkriteria dengan sub-kriteria lainnya, serta membandingkan kriteria dengan sub-kriteria. Nilai ini merupakan nilai yang diberikan oleh expert perusahaan.

\section{Perhitungan Pairwise Comparison}

Tahap selanjutnya dari metoda ANP adalah perhitungan matrik pairwise comparison dari nilai yang diberikan oleh expert pada kuisioner hubungan saling mempengaruhi antar kriteria, antar sub-kriteria, dan antar kriteria dengan sub-kriteria.

\section{Evaluasi Penyebab Risiko Dalam Analisa Mitigasi Risiko}

Tujuan dari evaluasi penyebab risiko adalah untuk membuat keputusan mengenai penyebab risiko mana yang memerlukan penanganan/ mitigasi dan prioritas penanganan risiko tersebut. Dalam evaluasi risiko ini dilakukan perbandingan level risiko yang ditemukan selama proses dengan metode ANP, analisa dengan kriteria risiko yang telah ditetapkan pada tahap penetapan konteks dalam risk treatment mencakup identifikasi range pilihan penanganan risiko, melakukan penilaian terhadap pilihan tersebut dan persiapan serta implementasi rencana treatment.
Setelah risiko dirubah atau dibagi (shared), maka kemungkinan terdapat residual risiko yang tetap ada, hal ini bisa terjadi bila terdapat kegagalan dalam mengidentifikasi risiko, membagi risiko, atau menangani risiko.

\section{Hasil dan Pembahasan \\ Identifikasi Risiko dan Penilaian Risiko}

Penilaian risiko dilakukan bersama-sama antara peneliti dengan safety officer. Kemudian dilakukan studi lapangan dan mempelajari laporan K3 untuk menentukan nilai $\mathrm{P}$ dan $\mathrm{D}$. Kemudian nilai $\mathrm{P}$ dan $\mathrm{D}$ yang telah ditentukan divalidasi oleh safety officer dari main kontraktor.

\section{Penentuan Goal dan Analisis Hubungan \\ Keterkaitan Antar Sub-Kriteria}

Kriteria dalam hal ini merupakan variabel kejadian risiko, kriteria ini digunakan untuk model ANP yang dapat menggambarkan kondisi nyata dari risiko proyek kontruksi. Kriteria yang digunakan dalam penelitian ini merupakan kejadian risiko berdasarkan tahapan dalam pengerjaan proyek kontruksi gedung bertingkat. Setiap tahap pengerjaan proyek akan memberikan jenis risiko dan nilai dari kejadian risiko serta dampak peluang yang ditimbulkan.

Sub-kriteria merupakan penyebab dari kejadian risiko yang disebabkan karena prilaku kerja. Penyebab terbesar dari kejadian risiko disebabkan oleh perilaku kerja. Hal yang sama dikemukan oleh Patriadini (2013) yang menyebutkan bahwa faktor manusia menjadi penyebab munculnya risiko pada kecelakan kerja di proses pembangunan proyek kontruksi.

Setelah penentuan kriteria yang merupakan kejadian risiko, tahap berikut menentukan sub-kriteria sebagai penyebab munculnya risiko kecelakaan kerja. Penentuan sub-kriteria dalam penelitian ini didasarkan pada penyebab kejadian risiko yang terkait dengan keselamatan kerja, dimana penyebab kecelakaan kerja disebabkan karena faktor manusia, faktor kontruksi, faktor alat kerja, faktor lingkungan. Seluruh penyebab dari kejadian risiko merupakan hasil diskusi dari expert dari proyek kontruksi. Hasil sub-kriteria tersebut ditunjukkan dalam Tabel 3. 
Tabel 1. Penilaian Risiko Kecelakaan Kerja

\begin{tabular}{|c|c|c|c|}
\hline Kejadian Risiko & $\begin{array}{c}\text { Nilai Peluang Risiko } \\
(\mathrm{P})\end{array}$ & $\begin{array}{l}\text { Nilai Dampak } \\
\text { Risiko (D) }\end{array}$ & $\begin{array}{c}\text { Nilai Tingkat Risiko } \\
\text { (R) }\end{array}$ \\
\hline Jatuh & 2 & 3 & 6 \\
\hline Terkena material tajam & 2 & 1 & 2 \\
\hline Tergores material & 3 & 2 & 3 \\
\hline Terguling & 2 & 2 & 4 \\
\hline Tertimpa material & 2 & 3 & 6 \\
\hline Alat terguling, terperosok & 2 & 3 & 6 \\
\hline Terperosok jatuh dalam lubang & 2 & 2 & 4 \\
\hline Kebisingan & 2 & 2 & 4 \\
\hline Terjepit mesin bar bender \& bar cutter & 2 & 2 & 4 \\
\hline Terjepit Terbentur alat kerja & 2 & 3 & 6 \\
\hline Truk terperosok, terjebak lumpur & 2 & 2 & 4 \\
\hline Mata Terkena Pecahan Beton & 2 & 2 & 4 \\
\hline Terkubur longsoran & 2 & 3 & 6 \\
\hline Terkena Swing Excavator & 2 & 2 & 4 \\
\hline Excavator terguling & 2 & 2 & 4 \\
\hline Tertabrak dumtruck & 2 & 2 & 4 \\
\hline Tersandung & 3 & 1 & 3 \\
\hline Tertusuk paku & 2 & 2 & 4 \\
\hline Terpeleset/ jatuh & 2 & 3 & 6 \\
\hline Tergores & 3 & 1 & 3 \\
\hline Terjepit & 2 & 3 & 6 \\
\hline Kejatuhan material & 2 & 3 & 6 \\
\hline Tertabrak truk mixer & 1 & 3 & 3 \\
\hline Mata terkena percikan beton & 2 & 2 & 4 \\
\hline Kulit terkena percikan beton & 2 & 1 & 2 \\
\hline Jatuh dari kolom & 2 & 3 & 6 \\
\hline Jatuh (penuangan beton dari bucket) & 2 & 3 & 6 \\
\hline Terbentur alat kerja & 2 & 1 & 2 \\
\hline Jatuh dari ketinggian & 2 & 3 & 6 \\
\hline Tertimpa baja dan material lainnya & 2 & 2 & 4 \\
\hline Tabung Gas meledak & 2 & 3 & 6 \\
\hline Tertimpa besi (diangkut dengan TC) & 2 & 3 & 6 \\
\hline Tergores besi & 3 & 1 & 3 \\
\hline Tersandung & 3 & 1 & 3 \\
\hline Jari tangan terjepit alat Bar Bender & 2 & 2 & 2 \\
\hline Terlindas alat & 2 & 2 & 4 \\
\hline Getaran alat & 2 & 1 & 2 \\
\hline Menghirup zat kimia & 3 & 1 & 3 \\
\hline Pasangan bata rubuh & 1 & 3 & 3 \\
\hline Percikan semen terkena mata & 2 & 2 & 4 \\
\hline Percikan semen mengenai kulit & 3 & 1 & 3 \\
\hline Hubungan arus pendek & 2 & 2 & 4 \\
\hline kelilipan & 3 & 1 & 3 \\
\hline Tangan tergores & 2 & 1 & 2 \\
\hline Memotong keramik & 2 & 2 & 4 \\
\hline Terkena percikan keramik & 3 & 1 & 3 \\
\hline Menghirup debu & 3 & 1 & 3 \\
\hline Kesetrum & 2 & 3 & 6 \\
\hline Terkena percikan api & 2 & 3 & 6 \\
\hline Jatuh dari ketinggian yang sama & 2 & 2 & 4 \\
\hline Jari terpotong & 2 & 2 & 4 \\
\hline Tangan tergores & 2 & 1 & 2 \\
\hline Terkena cairan Coating & 2 & 1 & 2 \\
\hline Semburan api & 2 & 2 & 4 \\
\hline Meledak & 2 & 3 & 6 \\
\hline Tertimpa pintu kayu saat pemasangan & 1 & 2 & 2 \\
\hline Menghirup gas & 2 & 2 & 4 \\
\hline Tersengat arus listrik & 2 & 3 & 6 \\
\hline Tertimpa material & 2 & 2 & 4 \\
\hline Terkena percikan semen & 2 & 1 & 2 \\
\hline
\end{tabular}


Tabel 2. Kriteria pada Model ANP

\begin{tabular}{ll}
\hline Kriteria & Kejadian Risiko \\
\hline Tahap & Jatuh, tertimpa material tajam, tersengat listrik, terkena material tajam, tergores material, \\
Persiapan (C1) & terguling, tumpah, tertimpa material \\
& Alat terguling terperosok, kebisingan, terperosok jatuh dalam lubang, terjepit mesin bar bender \\
Tahapan Sub & dan bar cutter, terjepit terbentur alat kerja, truk terperosok, terjebak lumpur, mata terkena \\
Struktur (C2) & pecahan beton, terkubur longsoran, terkena swing excavator, excavator terguling, tertabrak \\
& dumtruck \\
& Tersandung, tergores, tertusuk paku, terpeleset/ jatuh, terjepit, kejatuhan material, tertabrak truk \\
& mixer, mata terkena percikan beton, kulit terkena percikan beton, jatuh dari kolom, jatuh \\
Tahapan & (penuangan beton dari bucket), terbentur alat kerja, truk terperosok terjebak lumpur, jatuh dari \\
Pekerjaan & ketinggian, tertimpa baja dan material lainnya, tabung gas meledak, tertimpa besi (diangkut \\
Struktur (C3) & dengan TC), tergores besi, jari tangan terjepit alat bar bender, terlindas alat, getaran alat, terkena \\
& percikan beton, jatuh dari ketinggian \\
& Percikan semen terkena mata, menghirup zat kimia, pasangan bata roboh, percikan semen \\
& mengenai kulit, hubungan arus pendek, kelilipan, tangan tergores, memotong keramik, terkena \\
percikan keramik, menghirup debu, hubungan arus pendek, kesetrum, terkena percikan api, jatuh \\
Tahapan & dari ketinggian yang sama, jari terpotong, tersengat listrik, terkena cairan coating, semburan api, \\
Finishing (C4) & meledak, tertimpa pintu kayu saat pemasangan, hubungan arus pendek, menghirup gas, tertimpa \\
& material, terkena percikan semen,
\end{tabular}

Pada tahap berikutnya membuat model jaringan (network) ANP. Selengkapnya pada Gambar .1

\section{Analisa Hasil Pembobotan Kriteria dan Sub Kriteria}

Kriteria dalam penelitian ini merupakan risiko yang terjadi pada masing-masing tahapan dalam pekerjaan proyek kontruksi, sedangkan sub-kriteria merupakan penyebab munculnya risiko kecelakaan kerja. Hal ini bertujuan untuk mengetahui potensi penyebab terjadinya risiko kecelakaan kerja, dengan demikian risiko yang terjadi dapat diminimalisir dan dilakukan upaya pencegahannya terhadap potensi penyebab risiko tersebut.

Kuisoner pembobotan kriteria dan sub-kriteria diberikan tiga model keterkaitan yaitu keterkaitan antar kriteria, kedua keterkaitan antara kriteria dengan sub-kriteria, ketiga keterkaitan antara sub-kriteria. Pengolahan data menggunakan Sofware Matlab, yang diawali dengan pembuatan model hubungan kemudian dilakukan koding Matlab. Pembobotan dilakukan pada masing-masing kriteria, sub-kriteria dengan kriteria dan sub-kriteria itu sendiri. Hasil selengkapnya dapat dilihat pada Tabel 4 dan Tabel 5.

Pada Tabel 4 menunjukkan risiko kecelakaan kerja paling tinggi terdapat ada proses pekerjaan struktur. Hal ini dikarenakan tahap pekerjaan struktur merupakan tahapan yang dimulai belum adanya bangunan, maupun dinding dan lantai atau istilah lainnya membangun dari 0 sampai dengan ketinggian.
Sedangkan potensi risiko berikutnya yaitu pada tahap finishing dan risiko yang paling kecil yaitu persiapan.

Tabel 5 dan Tabel 6, menunjukkan bahwa penyebab terjadinya risiko $\mathrm{K} 3$ pada bidang kontruksi didominasi oleh kriteria struktur sebesar $44 \%$, dibandingkan dengan kriteria persiapan 17\%, kriteria sub struktur 21\% dan kriteria finishing 19\%. Penyebab risiko kecelakaan kerja yang palig besar disebabkan oleh faktor manusia sebesar 77\%, faktor ini disebabkan karena perilaku tidak aman. Begitu juga dengan Andi (2005) menyatakan, bahwa kecelakaan kerja pada proyek kontruksi yang berdampak pada luka ringan, maupun kematian berasal dari tindakan tidak aman yang dilakukan pekerja kontruksi. Salah satunya prilaku tidak aman seperti pekerja tidak menggunakan APD, pekerja tidak memperhatikan K3, bekerja sambil bergurau, pekerja tidak konsentrasi, melamun, bekerja tidak sesuai dengan SOP, terburuburu, pekerja tidak disiplin, pijakan kaki tidak memakai catwalk, hook pada safety hardness tidak dicantolkan di hook TC dll. Sedangkan penyebab risiko yang berasal dari faktor manusia dan alat yaitu, Scaffolding ambruk, terpleset, dikarenakan faktor manusia dan lingkungan. Untuk faktor manusia dan kontruksi penyebabnya dikarenakan tidak ada pegangan sehingga menimbulkan risiko terjatuh. Penyebab risiko suara proses pengeboran merupakan faktor alat dan kontruksi. Selengkapnya pada Tabel 6. 
Tabel 3. Sub Kriteria Kejadian Risiko

\begin{tabular}{|c|c|}
\hline Penyebab Risiko & Sub Kriteria \\
\hline Scaffolding ambruk & SK1 \\
\hline Terpleset & SK2 \\
\hline Pekerja tidak menggunakan APD & SK3 \\
\hline Kabel terkena air (korsleting) & SK4 \\
\hline Tersentuh aliran listrik & SK5 \\
\hline Kelelahan & SK6 \\
\hline Pekerja tidak memperhatikan K3 & SK7 \\
\hline Bekerja sambil bergurau & SK8 \\
\hline Kurang istirahat & SK9 \\
\hline Pondasi Scaffolding tidak padat pada tempat yang datar & SK10 \\
\hline Metode kontruksi tidak benar & SK11 \\
\hline Kurang hati-hati & SK12 \\
\hline Komitmen K3 kurang & SK13 \\
\hline Kurang pengetahuan $\mathrm{K} 3$ & SK14 \\
\hline Posisi alat salah & SK15 \\
\hline Alat kerja rusak & SK16 \\
\hline Pekerja tidak terlatih & SK17 \\
\hline Tidak mengikuti pelatihan K3 & SK18 \\
\hline Lokasi tanah becek, lumpur, amblas & SK19 \\
\hline Tidak ada rambu peringatan & SK20 \\
\hline Suara proses pegeboran & SK21 \\
\hline Pekerja Tidak Konsentrasi & SK22 \\
\hline Bercanda & SK23 \\
\hline Kesalahan transformasi informasi & SK24 \\
\hline Kesalahan dalam intruksi kerja & SK25 \\
\hline Posisi kerja salah & SK26 \\
\hline Material berantakan & SK27 \\
\hline Melamun & SK28 \\
\hline Tidak ada pegangan & SK29 \\
\hline Area kerja terbatas & SK30 \\
\hline Bekerja tidak sesuai dengan SOP & SK31 \\
\hline Terburu-buru & SK32 \\
\hline Kesalahan cara pengangkutan manual & SK33 \\
\hline Kurang maintenance & SK34 \\
\hline Kondisi peralatan yang sudah tua & SK35 \\
\hline Managemen kurang tanggap & SK36 \\
\hline $\begin{array}{l}\text { Tidak tau menggunakan alat dengan bar bender dan bar cutter dengan } \\
\text { benar }\end{array}$ & SK37 \\
\hline Tidak dilakukan barikade pada area pembersihan & SK38 \\
\hline Flash back aristor rusak & SK39 \\
\hline Hook pada safety hardness tidak dicantolkan di hook TC & SK40 \\
\hline Infeksi & SK41 \\
\hline Area sempit & SK42 \\
\hline Pekerja tidak disiplin & SK43 \\
\hline Kabel Terkelupas & SK44 \\
\hline Pijakan kaki tidak memakai catwalk & SK45 \\
\hline
\end{tabular}

Tabel 4. Rangking Pembobotan Kriteria

\begin{tabular}{ccc}
\hline Kriteria & Bobot & Rangking \\
\hline C3 & 0.615976 & 1 \\
C4 & 0.201534 & 2 \\
C2 & 0.136898 & 3 \\
C1 & 0.045593 & 4 \\
\hline
\end{tabular}


Tabel 5. Pembobotan Sub Kriteria terhadap Kriteria.

\begin{tabular}{|c|c|c|c|c|c|c|}
\hline \multirow{3}{*}{$\frac{\text { Sub kriteria }}{\text { SK1 }}$} & \multicolumn{4}{|c|}{ Kriteria } & \multirow{2}{*}{\multicolumn{2}{|c|}{ Bobot terbesar }} \\
\hline & \multirow{2}{*}{$\frac{\mathbf{C 1}}{0.13}$} & \multirow{2}{*}{$\frac{\mathbf{C 2}}{0.21}$} & \multirow{2}{*}{$\frac{\mathbf{C 3}}{0.29}$} & \multirow{2}{*}{$\frac{\mathbf{C 4}}{0.38}$} & & \\
\hline & & & & & 0.38 & $\mathrm{C} 4$ \\
\hline $\mathrm{SK} 2$ & 0.21 & 0.38 & 0.29 & 0.38 & 0.38 & $\mathrm{C} 2$ \\
\hline SK3 & 0.13 & 0.21 & 0.38 & 0.29 & 0.38 & $\mathrm{C} 3$ \\
\hline SK4 & 0.13 & 0.21 & 0.38 & 0.29 & 0.38 & C3 \\
\hline SK5 & 0.13 & 0.21 & 0.38 & 0.29 & 0.38 & $\mathrm{C} 3$ \\
\hline SK6 & 0.13 & 0.29 & 0.38 & 0.21 & 0.38 & $\mathrm{C} 3$ \\
\hline SK7 & 0.14 & 0.23 & 0.32 & 0.32 & 0.32 & C3.C4 \\
\hline SK8 & 0.25 & 0.25 & 0.25 & 0.25 & 0.25 & C1.C2.C3.C4 \\
\hline SK9 & 0.17 & 0.28 & 0.28 & 0.28 & 0.28 & C2.C3.C4 \\
\hline SK10 & 0.21 & 0.29 & 0.38 & 0.13 & 0.38 & C3 \\
\hline SK11 & 0.13 & 0.21 & 0.38 & 0.29 & 0.38 & $\mathrm{C} 3$ \\
\hline SK12 & 0.25 & 0.25 & 0.25 & 0.25 & 0.25 & C1.C2.C3.C4 \\
\hline SK13 & 0.25 & 0.25 & 0.25 & 0.25 & 0.25 & C1.C2.C3.C4 \\
\hline SK14 & 0.25 & 0.25 & 0.25 & 0.25 & 0.25 & C1.C2.C3.C4 \\
\hline SK15 & 0.25 & 0.25 & 0.25 & 0.25 & 0.25 & C1.C2.C3.C4 \\
\hline SK16 & 0.13 & 0.29 & 0.38 & 0.21 & 0.38 & $\mathrm{C} 3$ \\
\hline SK17 & 0.13 & 0.21 & 0.38 & 0.29 & 0.38 & $\mathrm{C} 3$ \\
\hline SK18 & 0.25 & 0.25 & 0.25 & 0.25 & 0.25 & C1.C2.C3.C4 \\
\hline SK19 & 0.25 & 0.32 & 0.32 & 0.11 & 0.32 & C2.C3 \\
\hline SK20 & 0.25 & 0.25 & 0.25 & 0.25 & 0.25 & C1.C2.C3.C4 \\
\hline SK21 & 0.05 & 0.45 & 0.35 & 0.15 & 0.45 & $\mathrm{C} 2$ \\
\hline SK22 & 0.13 & 0.29 & 0.38 & 0.21 & 0.38 & C3 \\
\hline SK23 & 0.13 & 0.29 & 0.38 & 0.21 & 0.38 & $\mathrm{C} 3$ \\
\hline SK24 & 0.25 & 0.25 & 0.25 & 0.25 & 0.25 & C1.C2.C3.C4 \\
\hline SK25 & 0.25 & 0.25 & 0.25 & 0.25 & 0.25 & C1.C2.C3.C4 \\
\hline SK26 & 0.25 & 0.25 & 0.25 & 0.25 & 0.25 & C1.C2.C3.C4 \\
\hline SK27 & 0.06 & 0.31 & 0.44 & 0.19 & 0.44 & $\mathrm{C} 3$ \\
\hline SK28 & 0.13 & 0.29 & 0.38 & 0.21 & 0.38 & C3 \\
\hline SK29 & 0.13 & 0.29 & 0.38 & 0.21 & 0.38 & C3 \\
\hline SK30 & 0.05 & 0.15 & 0.45 & 0.35 & 0.45 & $\mathrm{C} 3$ \\
\hline SK31 & 0.13 & 0.29 & 0.38 & 0.21 & 0.38 & C3 \\
\hline SK32 & 0.12 & 0.27 & 0.35 & 0.27 & 0.35 & C3 \\
\hline SK33 & 0.13 & 0.21 & 0.38 & 0.29 & 0.38 & C3 \\
\hline SK34 & 0.13 & 0.29 & 0.38 & 0.21 & 0.38 & $\mathrm{C} 3$ \\
\hline SK35 & 0.13 & 0.29 & 0.38 & 0.21 & 0.38 & $\mathrm{C} 3$ \\
\hline SK36 & 0.25 & 0.25 & 0.25 & 0.25 & 0.25 & C1.C2.C3.C4 \\
\hline SK37 & 0.13 & 0.38 & 0.38 & 0.13 & 0.38 & C2.C3 \\
\hline SK38 & 0.25 & 0.25 & 0.25 & 0.25 & 0.25 & C1.C2.C3.C4 \\
\hline SK39 & 0.25 & 0.25 & 0.25 & 0.25 & 0.25 & C1.C2.C3.C4 \\
\hline SK40 & 0.19 & 0.19 & 0.44 & 0.19 & 0.44 & $\mathrm{C} 3$ \\
\hline SK41 & 0.25 & 0.25 & 0.25 & 0.25 & 0.25 & C1.C2.C3.C4 \\
\hline SK42 & 0.25 & 0.25 & 0.25 & 0.25 & 0.25 & C1.C2.C3.C4 \\
\hline SK43 & 0.25 & 0.25 & 0.25 & 0.25 & 0.25 & C1.C2.C3.C4 \\
\hline SK44 & 0.13 & 0.29 & 0.38 & 0.21 & 0.38 & $\mathrm{C} 3$ \\
\hline SK45 & 0.13 & 0.29 & 0.38 & 0.21 & 0.38 & C3 \\
\hline
\end{tabular}

Pembobotan sub-kriteria dengan menggunakan Matlab ditunjukkan pada Tabel 7. Menghasilkan salah satu penyebab dasar timbulnya kecelakaan kerja terbesar pada tahap persiapan yaitu kurangnya pengetahuan $\mathrm{K} 3$ yang dapat menimbulkan risiko jatuh berkonsekwensi pekerja luka berat, cacat, permanen, meninggal dunia. Penyebab kecelakaan kerja pada sub struktur yaitu pekerja kurang disiplin. Sama halnya dengan hasil penelitian Maryani (2012) menghasilkan bahwa upaya untuk menurunkan atau menekan terjadinya kecelakaan kerja dapat dilakukan dengan meningkatkan kedisiplinan pekerja.

Pada kriteria finishing penyebab terjadinya kecelakaan kerja yaitu scaffolding ambruk selanjutnya. Bobot terbesar dari penyebab kecelakaan kerja dibanding dengan penyebab kecelakaan kerja lainnya yaitu pekerja tidak menggunakan APD, hal ini karena kurang kesadaran pekerja akan K3 walaupun bekerja di tempat yang mengandung bahaya. Padahal sistem manajemen keselamatan kesehatan kerja (K3) diwajibkan untuk menerapkannya hal ini termasuk bagian dari pengendalian proyek (Wicaksono, 2011). Risiko kecelakaan kerja pada tahap struktur cukup tinggi dibanding dengan risiko pada tahap persiapan, sehingga membuat risiko ini mendapat prioritas pertama untuk dilakukan pengendalian. 
Tabel 6. Faktor Penyebab Risiko Kecelakaan Kerja

\begin{tabular}{|c|c|}
\hline Penyebab Risiko & Faktor \\
\hline Scaffolding ambruk & Manusia - alat \\
\hline Terpleset & Manusia-Lingkungan \\
\hline Pekerja tidak menggunakan APD & Manusia \\
\hline Kabel terkena air (korsleting) & Alat Kerja \\
\hline Tersentuh aliran listrik & Alat kerja \\
\hline Kelelahan & Manusia \\
\hline Pekerja tidak memperhatikan K3 & Manusia \\
\hline Bekerja sambil bergurau & Manusia \\
\hline Kurang istirahat & Manusia \\
\hline Pondasi Scaffolding tidak padat pada tempat yang datar & Manusia \\
\hline Metode kontruksi tidak benar & Manusia \\
\hline Kurang hati-hati & Manusia \\
\hline Komitmen K3 kurang & Manusia \\
\hline Kurang pengetahuan $\mathrm{K} 3$ & Manusia \\
\hline Posisi alat salah & Manusia \\
\hline Alat kerja rusak & Alat \\
\hline Pekerja tidak terlatih & Manusia \\
\hline Tidak mengikuti pelatihan $\mathrm{K} 3$ & Manusia \\
\hline Lokasi tanah becek, lumpur, amblas & Lingkungan \\
\hline Tidak ada rambu peringatan & Manusia \\
\hline Suara proses pegeboran & Alat/Kontruksi \\
\hline Pekerja Tidak Konsentrasi & Manusia \\
\hline Becanda & Manusia \\
\hline Kesalahan transformasi informasi & Manusia \\
\hline Kesalahan dalam intruksi kerja & Manusia \\
\hline Posisi kerja salah & Manusia \\
\hline Material berantakan & Manusia \\
\hline Melamun & Manusia \\
\hline Tidak ada pegangan & Manusia-Kontruksi \\
\hline Area kerja terbatas & Kontruksi \\
\hline Bekerja tidak sesuai dengan SOP & Manusia \\
\hline Terburu-buru & Manusia \\
\hline Kesalahan cara pengangkutan manual & Manusia \\
\hline Kurang maintenance & Manusia \\
\hline Kondisi peralatan yang sudah tua & Alat kerja \\
\hline Managemen kurang tanggap & Manusia \\
\hline $\begin{array}{l}\text { Tidak tahu menggunakan alat dengan bar bender dan bar } \\
\text { cutter dengan benar }\end{array}$ & Manusia \\
\hline Tidak dilakukan barikade pada area pembersihan & Manusia \\
\hline Flash back aristor rusak & Alat kerja \\
\hline Hook pada safety hardness tidak dicantolkan di hook TC & Manusia \\
\hline Infeksi & Lingkungan \\
\hline Area sempit & Kontruksi \\
\hline Pekerja tidak disiplin & Manusia \\
\hline Kabel terkelupas & Alat \\
\hline Pijakan kaki tidak memakai catwalk & Manusia \\
\hline
\end{tabular}

Menurut Patradiani (2013) terdapat enam faktor yang mempengaruhi pekerja tidak menggunakan APD yaitu a) kurangnya kesadaran pekerja terhadap penggunaan APD, b) kurangnya pengetahuan pekerja terhadap penggunaan APD, c) Pekerja merasa tidak nyaman dalam menggunakan APD, d) APD yang tidak tersedia, e) pekerja merasa tidak ada pengawasan dari manajemen dan f) peraturan mengenai penggunaan APD yang kurang. Faktor ini saling mempengarui satu sama lainnya. Misalnya kurang kesadaran pekerja terhadap penggunaan APD disebabkan oleh kurangnya pelatihan dan sosialisasi perusahaan, tidak ada pengawasan dari manajemen mengenai penggunaan APD, peraturan penggunaan APD yang rendah.

Pada Tabel 6 menunjukkan adanya keterkaitan penyebab risiko kecelakaan kerja antar satu penyebab dengan penyebab yang lain dapat saling mempengaruhi. Penyebab risiko terpeleset disebabkan karena pekerja kurang hati-hati, bekerja sambil bergurau, kurang pengetahuan $\mathrm{K} 3$, tidak mengikuti pelatihan K3, komitmen pekerja terhadap K3 kurang. 
Tabel 7. Rangking Penyebab Risiko terhadap Kriteria

\begin{tabular}{|c|c|c|c|c|c|c|c|}
\hline $\begin{array}{c}\text { Sub } \\
\text { Kriteria } \\
\end{array}$ & Persiapan & $\begin{array}{c}\text { Sub } \\
\text { Kriteria }\end{array}$ & $\begin{array}{c}\text { Sub } \\
\text { Struktur }\end{array}$ & $\begin{array}{c}\text { Sub } \\
\text { Kriteria }\end{array}$ & Struktur & $\begin{array}{c}\text { Sub } \\
\text { Kriteria } \\
\end{array}$ & Finishing \\
\hline SK14 & 0.047 & SK43 & 0.065 & SK3 & 0.080 & SK1 & 0.077 \\
\hline SK43 & 0.045 & SK13 & 0.060 & SK4 & 0.066 & SK43 & 0.065 \\
\hline SK44 & 0.039 & SK14 & 0.056 & SK5 & 0.058 & SK13 & 0.064 \\
\hline SK18 & 0.033 & SK18 & 0.053 & SK10 & 0.051 & SK14 & 0.058 \\
\hline SK24 & 0.032 & SK19 & 0.048 & SK11 & 0.048 & SK18 & 0.052 \\
\hline SK28 & 0.029 & SK8 & 0.048 & SK13 & 0.043 & SK3 & 0.038 \\
\hline SK13 & 0.028 & SK2 & 0.041 & SK14 & 0.042 & SK4 & 0.037 \\
\hline SK19 & 0.028 & SK10 & 0.039 & SK16 & 0.040 & SK5 & 0.034 \\
\hline SK25 & 0.027 & SK16 & 0.038 & SK19 & 0.035 & SK2 & 0.033 \\
\hline SK4 & 0.026 & SK21 & 0.035 & SK18 & 0.034 & SK17 & 0.032 \\
\hline SK45 & 0.026 & SK6 & 0.034 & SK17 & 0.034 & SK11 & 0.031 \\
\hline SK32 & 0.025 & SK15 & 0.034 & SK22 & 0.031 & SK29 & 0.031 \\
\hline SK22 & 0.025 & SK12 & 0.030 & SK23 & 0.030 & SK30 & 0.031 \\
\hline SK2 & 0.024 & SK22 & 0.025 & SK28 & 0.027 & SK32 & 0.030 \\
\hline SK31 & 0.024 & SK17 & 0.025 & SK30 & 0.025 & SK39 & 0.029 \\
\hline SK39 & 0.024 & SK23 & 0.023 & SK29 & 0.025 & SK33 & 0.029 \\
\hline SK30 & 0.022 & SK28 & 0.021 & SK31 & 0.024 & SK7 & 0.025 \\
\hline SK23 & 0.022 & SK31 & 0.021 & SK32 & 0.023 & SK8 & 0.023 \\
\hline SK9 & 0.022 & SK32 & 0.020 & SK33 & 0.021 & SK6 & 0.020 \\
\hline SK8 & 0.022 & SK29 & 0.019 & SK21 & 0.021 & SK9 & 0.018 \\
\hline SK5 & 0.022 & SK34 & 0.019 & SK34 & 0.020 & SK16 & 0.017 \\
\hline SK10 & 0.021 & SK11 & 0.019 & SK35 & 0.019 & SK22 & 0.017 \\
\hline SK42 & 0.021 & SK35 & 0.018 & SK1 & 0.018 & SK12 & 0.016 \\
\hline SK1 & 0.020 & SK44 & 0.018 & SK6 & 0.016 & SK28 & 0.016 \\
\hline SK11 & 0.020 & SK45 & 0.016 & SK44 & 0.016 & SK23 & 0.014 \\
\hline SK7 & 0.019 & SK39 & 0.016 & SK2 & 0.014 & SK31 & 0.014 \\
\hline SK12 & 0.019 & SK24 & 0.016 & SK7 & 0.013 & SK35 & 0.013 \\
\hline SK27 & 0.019 & SK1 & 0.015 & SK8 & 0.012 & SK34 & 0.013 \\
\hline SK16 & 0.019 & SK9 & 0.014 & SK9 & 0.012 & SK44 & 0.010 \\
\hline SK40 & 0.019 & SK3 & 0.014 & SK43 & 0.012 & SK45 & 0.009 \\
\hline SK20 & 0.018 & SK4 & 0.014 & SK15 & 0.011 & SK15 & 0.009 \\
\hline SK35 & 0.018 & SK5 & 0.013 & SK40 & 0.009 & SK10 & 0.008 \\
\hline SK6 & 0.017 & SK7 & 0.013 & SK45 & 0.008 & SK19 & 0.008 \\
\hline SK33 & 0.017 & SK27 & 0.011 & SK20 & 0.008 & SK21 & 0.008 \\
\hline SK15 & 0.017 & SK33 & 0.009 & SK37 & 0.007 & SK27 & 0.008 \\
\hline SK41 & 0.016 & SK37 & 0.008 & SK39 & 0.007 & SK24 & 0.007 \\
\hline SK34 & 0.016 & SK42 & 0.0064 & SK12 & 0.007 & SK40 & 0.007 \\
\hline SK37 & 0.016 & SK30 & 0.0057 & SK24 & 0.006 & SK38 & 0.007 \\
\hline SK17 & 0.016 & SK40 & 0.0050 & SK27 & 0.006 & SK36 & 0.007 \\
\hline SK26 & 0.014 & SK36 & 0.0035 & SK41 & 0.005 & SK37 & 0.006 \\
\hline SK3 & 0.014 & SK41 & 0.0026 & SK25 & 0.004 & SK20 & 0.006 \\
\hline SK38 & 0.014 & SK38 & 0.0023 & SK38 & 0.003 & SK25 & 0.005 \\
\hline SK36 & 0.014 & SK25 & 0.0022 & SK26 & 0.003 & SK41 & 0.005 \\
\hline SK29 & 0.013 & SK26 & 0.0022 & SK42 & 0.003 & SK26 & 0.005 \\
\hline SK21 & 0.013 & SK20 & 0.0022 & SK36 & 0.002 & SK42 & 0.005 \\
\hline
\end{tabular}

\section{Upaya Pengendalian Risiko}

Pengendalian risiko merupakan upaya dalam menangani risiko yang bertujuan untuk mengendalikan penyebab terjadinya risiko kecelakaan kerja. Pengendalian yang dilakukan mayoritas ada pada tahap struktur, yang mana tahap struktur penyebab risiko yang mendominasi dibanding tahapan yang lainnya seperti persiapan, sub struktur, finishing. Pada Tabel 4 dan Tabel 5 terlihat bahwa faktor manusia merupakan penyebab terbesar timbulnya kecelakaan kerja pada proyek kontruksi. Oleh karena itu pengendalian dari sisi pekerja perlu mendapatkan prioritas yang utama untuk dilakukan terlebih dahulu karena menurut Anwar et.al (2014) kedudukan kesehatan dan keselamatan kerja melekat pada tenaga kerja kontruksi mulai dari manager sampai dengan pembantu tukang.

Pengendalikan risiko yang akan dilakukan dalam mengatasi penyebab risiko kecelakaan kerja diambil lima terbesar dari pembobotan sub-kriteria dengan kriteria. Adapun yang menyebabkan risiko dari lima besar tersebut antara lain: a) Kurang pengetahuan K3, b) Pekerja tidak disiplin, c) Pekerja tidak menggunakan APD, d) Scaffolding ambruk, e) Komitmen K3 kurang, f) Kabel terkena air korsleting, g) Kabel terkelupas, h) Tersentuh aliran listrik, i) Tidak mengikuti pelatihan K3, j) Pondasi scaffolding tidak rata, k) Kesalahan transformasi informasi, l) Lokasi becek, lumpur, amblas, m) Metode kontruksi tidak benar. 
Upaya pengendalian risiko kecelakaan kerja berdasarkan Handayani (2017b) yaitu :

1) Setiap pendirian scaffolding harus diinspeksi oleh seorang Scaffolder yang bersertifikat, 2) Metode kerja harus mengikuti SNI (Standar Nasional Indonesia), 3) Perbaikan manajemen K3, 4) Isolasi sambungan kabel mengikuti standar PUIL 2000 (Peraturan Umum Instalasi Listrik), 5) Mengikuti standar K3 untuk pekerjaan di ketinggian, 6) Penempatan rambu-rambu dan pengamanan lokasi kerja, 7) Melakukan Safety Morning dan Safety Induction, 8) Setiap pendirian scaffolding harus diinspeksi oleh seorang Scaffolder yang bersertifikat, 9) Menerapkan standar Keselamatan K3 pada pekerjaan kontruksi Highrise Building, 10) mempelajari MSDS (Material Safety Data Sheet)

\section{Kesimpulan}

Kecelakaan kerja pada proyek kontruksi disebabkan oleh faktor manusia yang lalai terhadap keselamatan kerja dengan berprilaku tidak aman di tempat kerja. Potensi terbesar risiko kecelakaan kerja terdapat pada proses struktur berikutnya finishing, sub struktur dan tahap persiapan. Pengendalian risiko dilakukan sesuai dengan potensi penyebab timbulnya risiko kecelakaan kerja yaitu dengan cara melakukan pendekatan melalui perbaikan manajemen K3 dan menerapkan standar K3 guna meningkatkan komitmen K3. Dengan adanya pengendalian risko diharapkan dapat meminimalkan risiko (zero accident) pada pekerjaan kontruksi.

\section{Ucapan Terima Kasih}

Terima kasih disampaikan kepada Menristek Dikti yang telah mendanai keberlangsungan Penelitian ini melalui Hibah penelitian Skim Dosen Pemula pendanaan 2017

\section{Daftar Pustaka}

Adiyanto., \& Irawan. (2013), Manajemen Risiko Keselamatan Dan Kesehatan Kerja (K3) Pada Pekerjaan Struktur Bawah Dan Struktur Atas Gedung Bertingkat, Tesis Master, Jurusan Teknik Sipil Fakultas Teknik Universitas Diponegoro Semarang.

Anwar., Farida., \& Ismail. (2014), Analisis Manajemen Risiko dan Keselamatan Kerja (K3) Pada Pekerjaan Upper Struktur Gedung bertingkat, Jurnal STT Garut, ISSN : 2302-7312 Vol. 13 No. 1
Andi. (2005) Model Persamaan Struktural Pengaruh Budaya, Keselamatan Kerja pada Prilaku Pekerja di Proyek Kontruksi, Jurnal Teknik Sipil, vol 12 No 3, pp 127-136

Anny, M. (2012). Pemodelan Kecelakaan Kerja Konstruksi Yang Komprehensif Untuk Mengendalikan Biaya K3, Tesis Master, Institut Teknologi Sepuluh Nopember, Surabaya, hal 3-5

Bottero, M., \& Ferretti, V., (2011). An Analytic Network Process-based Approach for Location Problems: The Case of a New Waste Incinerator Plant in the Province of Torino (Italy). Journal of Multi-Criteria Decision Analysis, 17, 63-84.

Handayani, D.I. (2017a). Causal Effects Diagram Dalam Memodelkan Risiko K3 Dengan Mempertimbangkan Keterkaitan Penyebab Risiko Pada Gedung Bertingkat, Seminar Nasional Teknik Industri (SNTI) Dan Seminar Nasional Terpadu Keilmuan Teknik Industri (Satelit), Jurusan Teknik Industri Universitas Brawijaya Malang.

Handayani, D.I. (2017b). The Design Of Mitigation Model Of Work Accident Risk By Applying Interpretive Structural Modeling Method. In International Conference on Maritim Science and Technology, Indonesia Naval Tehcnology College

Handayani, D.I. (2014). Penilaian Risiko Keselamatan Kesehatan Kerja, Jurnal Dinamika Rekayasa, Volume 10 No 2, ISSN 1858-3075

HTTP://properti.kompas.com/read/2015/.../Angka.Kec elakaan.Masih.Tinggi.Siapa.yang.Peduli

Laporan Tahunan Jamsostek Tahun 2010

Rury, P. (2013). Model Pengembangan Manajemen Risiko Kecelakaan Kerja Dengan Fokus Pada Perilaku Pekerja Di Industri Kimia, Tesis Master, Institut Teknologi Sepuluh Nopember, Surabaya, hal $15-17$

Wirahadi, K. R. D.(2007). Makalah Tantangan Masalah Keselamatan Dan Kesehatan Kerja Pada Proyek Konstruksi Di Indonesia, Jurusan Teknik Sipil Institut Teknologi Bandung.

Wicaksono, I. K. (2011). Manajemen Risiko K3 (Keselamatan dan Kesehatan Kerja) Pada Proyek Pembangunan Apartemen Puncak Permai Surabaya, Prosiding Seminar Nasional Manajemen Teknologi XIII, Hal A-54-2 - A-54-8 